\title{
Macroeconomic Impact of HIV and AIDS on the Zimbabwean Economy: A Human Capital Approach
}

\author{
Innocent Matshe ${ }^{1}$ and Obert Pimhidzai ${ }^{2}$
}

\begin{abstract}
Zimbabwe is one of the countries severely affected by the HIV/AIDS epidemic. The high prevalence of the disease is not only a health problem but has become an economic problem, yet little effort had previously been directed at establishing the exact magnitude of HIV/AIDS' economic impact. Using a human capital approach which measures the value of production lost as a result of HIVIAIDS related morbidity and mortality and values an infected person's economic return to society using an individual's annual income, the study establishes that HIV/AIDS has resulted in significant output losses for the Zimbabwean economy. About 13.32\% of 1993 GDP at factor cost (was lost due to HIV/AIDS in the years 1994 to 2003. The macroeconomic impact of HIVIAIDS is severe and can therefore not be ignored even if the prevalence drops to zero in the present period.
\end{abstract}

Keywords: HIV/AIDS, human capital, Zimbabwe, macro-economy

\section{Introduction}

The HIV/AIDS epidemic is a health and development crisis in Zimbabwe. In the year 2003, 24.6\% of the entire adult population (ages 15-49) was affected by HIV/ AIDS. This means that 1.8 million people out of 11.6 million people are infected by the HIV virus, while an average of 2500 people per week die as a result of HIV/ AIDS, making Zimbabwe one of the most seriously affected countries in the world.

HIV/AIDS requires special treatment because the disease has a long incubation period thus, the impact of the existing levels of infection will be felt for a long time after the initial infection. Generally, the working age-group is the most affected in developing countries; and the number of infected persons is large and there are no signs of reduced incidence to minimal levels. In addition there is currently no cure for AIDS.

For these reasons, HIV/AIDS has wide implications not only as a health problem but as a socio-economic problem as well. AIDS has far reaching impacts on vulnerability to other diseases, the fiscal budget, agriculture and food security, social structure and Gross Domestic Product of the country. According to the Ministry of Health and Child Welfare (MOHCW), the number of TB case rose by $400 \%$ between 1990 and 1999. This surge is attributed to increases in HIV infections. As of 1998, the costs of conventional care for HIV and AIDS related illnesses were estimated to 
have increased the MOHCW budget by $60 \%$. This, together with increased morbidity and mortality have direct implications on the macroeconomic performance of the Zimbabwean economy.

Although there is a general consensus that HIV/AIDS poses severe macroeconomic effects, very little empirical effort has been directed at quantifying or measuring the magnitude of this impact. This study is therefore aimed at making a contribution towards establishing the magnitude of HIV/AIDS' macroeconomic impact on Zimbabwe. Most studies on the measurement of the economic costs of HIV/AIDS adopt mostly one of two approaches, either the direct cost approach focusing on the cost of prevention and treatment of HIV/AIDS or any indirect cost approach that measures the value of production lost as a result of HIV/AIDS - related morbidity and mortality, and resource allocation implications of coping measures adopted at the national levels. Measurement of the macroeconomic impact of HIV/AIDS falls within this last category. A human capital approach outlined in section 3 of the study shall be used to compute the output lost due to HIV/AIDS.

The study is organised as follows: Section 2 presents the analytical framework of the study. Section 3 outlines and develops a model for computing output lost due to HIV/AIDS-related morbidity and mortality using a human capital approach. The results of the study are presented and discussed in Section 4, while the conclusion and areas of future study are discussed in Section 5.

\section{Analytical Framework}

That HIV/AIDS leads to output losses is a generally accepted fact. These output losses are partly a result of the negative impact HIV/AIDS has on the existing human capital stock and the ability to accumulate more human capital. HIV/AIDS diminishes and incapacitates the existing pool of skilled labour through death, absenteeism, increased turnover rates and training costs associated with new recruitments. All these result in increased costs to firms (direct cost of HIV/AIDS) and output losses (indirect losses that are a result of lost productivity) to the economy in general, most notably due to reduction in labour supply (in hours or days). The major issue is that of quantifying the magnitude of this output loss. A human capital model tries to quantify output losses which are a direct consequence of reduced worker productivity because of absenteeism due to either HIV/AIDS illness or death and values an infected person's economic return to society using an individual's annual income.

The approach taken is to calculate the discounted weighted healthy life years lost due to HIV/AIDS and evaluate loss in output using infected individuals' future earnings to make forecasts on output losses due to HIV/AIDS. Although the approach seems very attractive, it involves assumptions about highly volatile economic variables. Assumptions about future earnings, interest rates, inflation and output fluctuations will have to be made. The accuracy of the predictions of these variables is doubtful for economies like Zimbabwe that are characterised by frequent policy reviews and reversals. To avoid this pitfall, the study establishes past loss in output attributable to HIV/AIDS in the Zimbabwean economy for the period starting 
1994 to 2003 using a similar approach but measuring past output losses attributable to HIV/AIDS instead of projecting future losses. Quantifying past losses is much easier and more accurate given that recorded rather than predicted data is used.

An alternative approach would be to analyse the impact of reduced labour supply due to HIV/AIDS on macroeconomic variables like prices and GDP growth rate, their effect on demand and resource allocation. Such an analysis can only be carried out in a CGE framework because the direct impact of reduced labour supply due to HIV/AIDS is difficult to measure in the presence of not only high unemployment that characterise the Zimbabwean economy, but also the effect of such a reduction on multi-sectoral interactions and their adjustment process. The human capital approach is therefore, deemed to be the most appropriate in measuring the direct loss in output as a result of HIV/AIDS.

Several stages are involved in the computation of output loss due to HIV/AIDS using the human capital approach.

\subsection{Stages of Progression from HIV infection to AIDS}

Generally, HIV infection does not have a spontaneous effect on the health status of an individual or on output. It may take some time before symptoms of AIDS may be manifested in an individual, i.e. there is time lapse between the time of infection and when one begins to show signs/symptoms of HIV/AIDS. There are four stages/ phases of progression from infection to AIDS, namely:

1. Primo-infection /pre-antibody - Most infected individuals, approximately $30 \%$, will experience symptoms similar to the flu (influenza) or mononucleosis (fever, headaches, sore throat, skin rash, fatigue, muscular aches and pains, etc.) in the weeks subsequent to the entry of HIV into the body. It is at this stage of the infection that the infected individual is said to be in "primo-infection". These symptoms resolve spontaneously with time and the infection then progresses into its second stage.

2. Asymptomatic stage (Sero-positive without symptoms) - Most patients in this stage of infection feel well and have no physical complaints pertaining to the virus. The virus can live in the body for several years (5-7 years on average, with a great deal of individual variability) without manifesting its presence - this may be termed a latent phase.

3. Symptomatic stage (Sero-positive with HIV related symptoms) - In this stage, an infected person begins to suffer symptoms related to viral progression. Symptoms may include fever, nocturnal sweats, weight loss, swollen and/or sensitive lymph nodes, chronic diarrhoea, skin rashes, etc.)

4. AIDS - When the immune system has been severely compromised or damaged, the infection enters into its fourth phase which is AIDS. People with AIDS often suffer infections of the lungs, intestinal tract, brain, eyes, and other organs, as well as debilitating weight loss, diarrhoea, neurological conditions, and cancers such as Kaposi's sarcoma and certain types of lymphomas. 
Untreated HIV disease is characterised by a gradual deterioration of immune function. Most notably, crucial immune cells called CD4 positive (CD4+) T cells are disabled and killed during a typical course of infection. These cells, sometimes referred to as "T-helper cells," play a central role in immune response by signalling other cells in the immune system to perform their special functions. A healthy, uninfected person usually has 800 to $1,200 \mathrm{CD} 4+\mathrm{T}$ cells per cubic millimetre (mm3) of blood. During untreated HIV infection, the number of these cells in a person's blood progressively declines. With a drastic reduction in T4 cells, the ability to respond against potential disease is reduced. Germs which ordinarily would have no effect on the body become potent enemies. When the CD4+ T cell count falls below $200 / \mathrm{mm}^{3}$, a person becomes particularly vulnerable to opportunistic infections and cancers that typify AIDS, the end stage of HIV disease. The T4-cell count in an infected person's blood can thus be used as a marker of an infected person's phase of progression.

The first phase of HIV infection has a negligible impact on output as it is associated with illnesses that do not necessarily lead to output loss as they are minor hence, do not lead to absenteeism from work or reduced hours of work. In the second phase, there are no symptoms of AIDS at all and a person carries out his/her normal duties. It is, therefore, assumed that there is no loss in output at this stage. However, in the third stage, an infected person starts to show symptoms of HIV/AIDS. There is a direct loss in output involved. The amount of output loss will be dependent on the impact of HIV/AIDS on the infected person's productivity compared to productivity in perfect health.

Assumptions made on (a) the disability weights attached to each stage of progression and (b) the transition rate from one stage to the other will have important implications on the measurement of the magnitude of output lost due to HIV/AIDS - related illness and death. Firstly, a morbidity index is required for measuring the level of disability associated with each stage of progression.

\subsection{Disability weighting at each stage of progression}

The standard disability weights and disability weighting at different levels of illness are generally classified into six categories that are defined in the table 1.

\section{Table 1: Definitions of disability weightings}

\begin{tabular}{|c|c|c|}
\hline $\begin{array}{l}\text { Disability } \\
\text { class }\end{array}$ & $\begin{array}{l}\text { Disability } \\
\text { weight }\end{array}$ & Class definition \\
\hline class 1 & 0.096 & $\begin{array}{l}\text { Individuals have limited ability to perform at least } \\
\text { one activity in one of the following areas: recreation, } \\
\text { education, procreation or occupation }\end{array}$ \\
\hline class 2 & 0.22 & $\begin{array}{l}\text { Individuals have limited ability to perform most activities } \\
\text { in one of the following areas: recreation, education, } \\
\text { procreation or occupation }\end{array}$ \\
\hline
\end{tabular}




\begin{tabular}{|l|l|l|}
\hline \hline class 3 & 0.4 & $\begin{array}{l}\text { Individuals have limited ability to perform activities in } \\
\text { two or more of the following areas: recreation, education, } \\
\text { procreation or occupation }\end{array}$ \\
\hline class 4 & 0.6 & $\begin{array}{l}\text { Individuals have limited ability to perform most activities } \\
\text { in two or more of the following areas: recreation, } \\
\text { education, procreation or occupation }\end{array}$ \\
\hline class 5 & 0.81 & $\begin{array}{l}\text { Individuals need assistance with instrumental activities } \\
\text { of daily living such as meal preparation, shopping or } \\
\text { housework }\end{array}$ \\
\hline class 6 & 0.92 & $\begin{array}{l}\text { Individuals need assistance with activities of daily living } \\
\text { such as eating, personal hygiene or toilet use }\end{array}$ \\
\hline
\end{tabular}

The second and third stages of progression can each be divided into two phases according to the levels of T4-cell count and bring the number of phases of progression to six. To the first phase, a class 1 disability weight is attached, class 2 to the second phase, and so on up to the sixth stage to which a class 6 disability weight is attached.

\subsection{Identification of stages and the transition period}

Longini, et al. (1991) modelled the progression from infection to aids using T4 cell decline in a staged progression model. They defined six stages of HIV infection for individuals who have not yet been diagnosed with AIDS and estimated the transition rates for each stage of progression. Their results are the basis on which we identify the transition period for this study. These are presented in table 2 below.

\section{Table 2: Transition rates from HIV infection to AIDS}

\begin{tabular}{|l|l|l|l|l|l|}
\hline $\begin{array}{l}\text { Clinical } \\
\text { indicator } \\
\text { staging }\end{array}$ & $\begin{array}{l}\text { t4-cell } \\
\text { count } \\
\text { interval }\end{array}$ & $\begin{array}{l}\text { Transition } \\
\text { rate } \\
\text { gin months }\end{array}$ & $\begin{array}{l}\text { Standard } \\
\text { Deviation }\end{array}$ & $\begin{array}{l}\text { Mean } \\
\text { waiting } \\
\text { time in } \\
\text { (years) }\end{array}$ & $\begin{array}{l}\text { Cumulative } \\
\text { waiting time } \\
\text { (years) }\end{array}$ \\
\hline pre-antibody & $>899$ & 0.0764 & 0.0051 & 1.1 & 1.1 \\
\hline asymptomatic & $700-899$ & 0.0665 & 0.0033 & 1.3 & 2.4 \\
\hline asymptomatic & $500-699$ & 0.0499 & 0.0021 & 1.7 & 4.1 \\
\hline symptomatic & $350-499$ & 0.0429 & 0.0019 & 1.9 & 8 \\
\hline symptomatic & $200-349$ & 0.0408 & 0.0022 & 2 & \\
\hline
\end{tabular}




\begin{tabular}{|l|l|l|l|l|r|}
\hline Aids & $1-199$ & 0.0529 & 0.0035 & 1.6 & 9.6 \\
\hline
\end{tabular}

The estimated mean waiting time from sero-conversion to when the T4 cell count is persistently below 500 is 4.1 years, the mean waiting time until it is below 200 is 8 .0 years, and the above mean waiting times from sero-conversion to AIDS diagnosis is 9.6 years. For purposes of this study, the mean waiting time for each stage is adopted and used as the transition time for each of the respective stages.

\subsection{Transition matrix}

The impact on output at each of the phases of progression from HIV infection to AIDS will differ depending on disability weightings at each stage. Therefore, a transition matrix revealing the HIV/AIDS incidence, prevalence and phases of progression from HIV infection to AIDS for the HIV/AIDS infected persons in any given year has to be constructed if a comprehensive analysis in quantifying output losses is to be made. The transition matrix captures the total number of HIV/AIDS infected persons in a given year and the number of people in a particular stage of progression in each year. The phases of progression from HIV/AIDS infection to AIDS, their time frames and the morbidity weights for each of the phases established above are key to the construction of the transition matrix.

In a simple transition matrix (as used for this study) all people infected in the same period are assumed to progress to the next stages at the same time. A more complicated matrix for different progression rates is whereby probabilities of progression to the next stage within a given time period are assigned to allow for the fact that some people progress faster than the expected rate while others progress slowly. In this study, we shall assume that those who progress faster will be offset by those who lag behind such that the number of people in each stage of progression in a particular period will be the same whether probabilities are used or not.

After the transition matrix has been constructed, earnings for each period have to be established. Assuming that earnings are closely related to labours' contribution in the production process, the average earnings will be a true reflection of a worker's output contribution for the year. The death of an economically active person will thus lead to a loss in output equivalent to the yearly average earnings for the following years, up to the last time period under consideration. Output losses due to HIV/AIDS in a given year is quantified by simply taking the product of the number of infected persons at each phase of progression in a given year, morbidity weights for each phase and the average earnings for that year. The total losses for the entire period is the sum total of the yearly losses due to HIV/AIDS. Sub-divisions of the earnings by location, skills category, or economic activity may be required if it is assumed that the rate of progression differs according to location, labour categories or industrial sectors. 


\section{Data}

HIV incidence and prevalence data was obtained from the Ministry of Health and Child Welfare. Consistent monthly data for 73 districts and referral hospitals across the country's 10 provinces was available only for the years 1994 to 2003. Data obtained after the second quarter of 2004 was found to be inconsistent and unreliable and therefore was not included in this study. For some areas, data is completely missing and in other instances, the way it is recorded makes it difficult for research to accurately attribute illness.

It should, however, be noted that the data on HIV incidence is not based on a number of new sero-positive individuals but on the number of new HIV-related diseases. This has implications on the stage progression, identification and disability weighting for each of the stages. Since the recorded data is on new cases of HIVrelated conditions, it shall be assumed that the data captures only those people who are in the third stage of progression (symptomatic stage) characterised by symptoms of HIV/AIDS. These individuals are captured because they sought medical attention as a result of illnesses associated with this stage of progression. Thus, for the purpose of the study, it shall be assumed that in the period of incidence, the patients are in the third stage of progression with a T4-cell count in the range $500<$ T4-count $<359$ with a disability weight of 0.6 attached to it.

Data of the source of earnings was collected from the Central Statistics Office (CSO) Quarterly Digest of Statistics. This data is available according to sectors and selected cities and towns, namely Bulawayo, Chinhoyi, Gweru, Harare, Kadoma, Kwekwe, Marondera, Masvingo and Mutare. Since the HIV incidence data is provided according to districts, output loss calculation was on the basis of incidence in these cities and towns and it was based on the earnings of the major economic activity for other places. These other places are mainly rural, farming and mining areas for which earnings from agriculture, forestry, fishing and mining sectors were used, respectively. Since quarterly data on the GDP deflator is not available, the CPI was used instead. The CSO data showed a very high positive correlation between the GDP deflator and the Consumer Price Index.

\section{The Model}

A simple human capital model in which output loss attributable to HIV/AIDS is measured by the value of discounted productive healthy life years lost due to HIV/ AIDS morbidity is employed.

Total morbidity due to HIV/AIDS in period $t,\left(M_{t}^{k}\right)$ can be represented by the following equation

$$
M_{l t}=\sum_{i} h_{i}^{k} d_{i}
$$

Where $d_{i}$ is the disability weighting of class $i$ and $0<i<1 ; h_{t i}^{k}$ be the number of people with HIV - related illness with a disability weighting $i$ in period $t$ in area $k$. Output lost due to HIV/AIDS morbidity is 
$Q_{k}=E_{k} M_{k}$

Where $E_{k t}$ denotes earnings per worker in period $t$ and $Q_{t}$ is output lost due to HIV/ AIDS morbidity. Substituting for $M_{l t}$ in equation 1 gives

$$
Q_{k}=E_{k} \sum h_{i}^{k} d_{i}
$$

Total output loss for a given period is thus

$$
Q=\sum_{k} \sum_{t} E_{k} M_{k}
$$

Since earnings per worker are in nominal figures, output loss from equation 4) will also be nominal. The total output lost is over time such that output lost should be expressed in real terms if a meaningful comparison is to be made. This is achieved by converting nominal output lost in each period to real output using an appropriate deflator $\left(v_{t}\right)$ for each time point. Real output lost over the entire period is thus expressed as

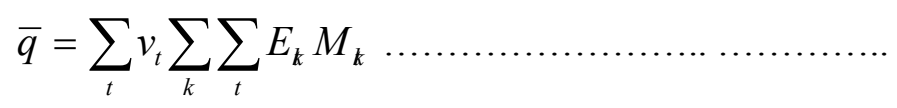

Alternatively, the present value approach, whereby the present value of the total output loss is calculated can be used. In period $t_{0}$, the present value of output loss is given by the following formula

$$
\widehat{q}=Q_{0}+\sum_{t=1}\left(\frac{Q_{t}}{\prod\left(1+r_{t}\right)}\right) \ldots \ldots \ldots \ldots
$$

Where $Q_{0}$ is output loss in the base period and $r_{t}$ is the interest rate in period $t . \bar{q}$ and $\widehat{q}$ measure output lost due to HIV/AIDS morbidity and are meaningfully comparable to the initial period's total output.

\section{Assumptions of the model}

The following are the basic assumptions of the model: (a) workers' earnings reflect workers' contribution to output; (b) the transition periods are the same across sectors, skills levels and cohort's age, however incidence and prevalence rates may be different; and (c) the output impact of morbidity is the same for both the non working age-cohorts and the working age cohorts because although indirect, caring for a sick but economically non-active person also takes the productive time of a working age person resulting in output loss of the carer. The model does not separate incidence into economically active and non-active groups. This thus implies that it is assumed that incidence rates for both the economically active and the economically non-active are the same. This assumption may be substantiated on the basis that the 
economically non-active are generally less informed and more likely to engage in risky behaviour. On the other hand, the Zimbabwean cultural system is such that people with higher income could be more prone to having more than one sexual partner, hence equally exposed to infection as well. This assumption however, can be relaxed by adjusting total output lost in proportion to the number of economically active persons in the economy. Lastly, age was also not considered in Longini, et al. (1991)'s model from which the transition rates used in this study are adopted.

\section{Results}

Equations 5 and 6 were used to compute GDP loss attributable to HIV/AIDS. The results show that the impact of the disease on output was considerable. Nominal output lost during the decade 1994-2003 was \$103.67 billion. Using equation (5), this translates to total output loss due to HIV/AIDS of $\$ 5.17$ billion in 1994 constant prices (or 13.32\% of 1993 GDP at factor cost). The January 1994 present value of output lost due to HIV/AIDS is 3.85 billion, which translates to $9.93 \%$ of 1994 GDP at factor cost. In 2003 prices, this amount translates to $\$ 1.61$ trillion (or $13.01 \%$ of 2003 GDP at factor cost). These results are in line with the projections made for the Southern African Countries like Zambia for which a 9\% GDP loss was forecasted for the period 1994-2000 and a 17\% loss in South Africa's GDP by 2010. In real terms, the amount lost in Zimbabwe falls within the same range.

Figure 1 shows the trend of output loss due to HIV/AIDS. The trend of real output lost due to HIV/AIDS shows a general increase since 1994 up to 2000 in which output lost shot to $\$ 300$ million (in 1994 constant prices) in the second quarter of 2000 from a mere $\$ 0.5$ million in the first quarter of 1994 . Although one can argue that data recording techniques also improved significantly in this period hence, increasing measurable output loss, it still remains a fact that HIV incidence rates increased enormously during the period and reached a peak of 33\% in the year 2000 . At this time, Zimbabwe was second only to Botswana in HIV/AIDS incidence in the whole world.

The upward trend on output lost reversed from the last quarter of 2000, since then the amount of output loss attributable to HIV/AIDS has been declining. Although, incidence rates declined to $24 \%$ in 2003 , the effect on reducing output loss is only minimal because HIV/AIDS illness is long term, it takes a long time for reduced incidence to have an impact on output loss due to HIV/AIDS (by reducing loss in output). Using the transition rates adopted in this study for example, zero HIV incidence in year 2005 would have translated to zero output loss only in the year 2015, thus HIV/AIDS has made a dent whose negative impact shall be felt for a long time in the Zimbabwean economy.

To a great extent, this downward trend is attributable to the rapid decline in the Zimbabwean economy, where $50 \%$ contraction of the manufacturing sector was experienced over the period 2000-2003. Due to high levels of inflation that characterised this period, real earnings for the period declined dramatically leading to the observed trend. Thus, the decline is largely attributed to reduced earnings rather than reduced incidence, otherwise the upward trend would have continued if 
exogenously determined workers' earnings had been adjusted according to inflation. However, one can still counter this line of thought by the fact that the earnings were truly reflective of workers contribution to GDP as their decline occurred during the period in which GDP was declining as well. It can be observed that the trend for the output lost (in January 1994 present value terms) continued to increase until the second quarter of 2003 when it reached its peak and started to decline. The observed trend is largely a result of suppressed interest rates from the year 2000 until the last half of 2003 .

\section{Figure 1: Trend in Output Lost Due to HIV/AIDS}

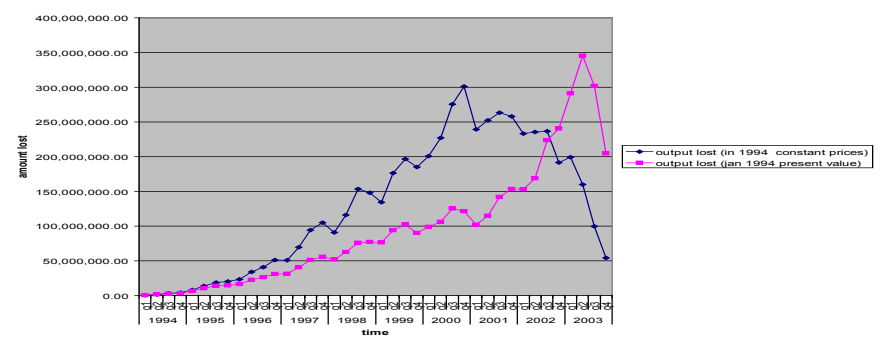

Since 2000, Zimbabwe's credit worthiness in foreign investors' perception deteriorated such that domestic borrowing and seignorage became the only sources of deficit financing. As such domestic interest rates were controlled so that domestic borrowing can be sustainable for the government. In this regard the present value approach may not give a true reflection of total output lost due HIV/AIDS hence, the real output measurement was preferred in this study.

As mentioned above, the decline in output lost due to HIV and AIDS since 2000 is attributable to a decline in real earnings rather than a decline in morbidity. Separating the impact of morbidity and the impact of a decline in earnings yields some interesting insights. Assuming exogenously determined earnings set at the average earnings for 1998, the output lost due to HIV and AIDS starts increasing continuously and almost linearly. Two factors contribute to this. The first is that the output lost is now a function of morbidity hence, we begin to capture morbidity trends rather than output loss due to HIV and AIDS. This trend is increasing because HIV and AIDS morbidity is cumulative. The second is that the number of productive healthy life years lost due to HIV and AIDS increases continuously in the early years until the effect of premature illness and death due HIV and AIDS is exhausted at a point where death or illness would have occurred in the absence of HIV and AIDS. It therefore, becomes clear that when measuring the impact of HIV and AIDS on output, one cannot separate the issue of morbidity and those of productivity. Output lost is a combination of the two. In other words, increasing morbidity on unproductive persons has a minimal output impact compared to increasing morbidity on highly productive persons. On the other hand, an impact of an increase in HIV and AIDS morbidity on output can be easily countered by preserving the productiveness of the infected persons.

Subdivision of output lost by areas show that Bulawayo, the second largest city with a population of 676787 , is the largest contributor (43\%) to output lost due to HIV/AIDS in the period under review. This is attributable to high HIV/AIDS cases recorded in this city, but cannot be explained by any other obvious socio-demographic variable. The null hypothesis that prevalence in the city is equal to mean prevalence 
in all other areas was rejected against the alternative that HIV/AIDS prevalence in the city is above that of all other areas. Despite having $52 \%$ of the country's population and a prevalence rate of $33 \%$ in 2003, rural areas, contributed only $9 \%$ of output loss due to HIV/AIDS. Agriculture (mainly grain production) is the main economic activity in rural areas. Due to the subsistence nature of rural agriculture, their contribution to GDP is below the average contribution of agriculture to the economy. In addition, rural earnings are very low and production is seasonal and thus, vulnerable to droughts. Since the Fast Track Land Redistribution Programme in 2000, the contribution of agriculture to the economy has declined as agriculture production has declined to critical levels, a situation compounded by persistent droughts since 2002. The areas that are second and third largest contributors to output lost due to HIV/AIDS are Mutare (18\%) and Harare (14\%), respectively. Since Harare (including its dormitory satellites - Chitungwiza and Norton) has a very large population (3 million people) and is the hub of Zimbabwe's economic activities, it is widely expected that it should have been the largest contributor to output loss attributable to HIV/AIDS. The result obtained is therefore widely unexpected. However, unlike widely used data, recorded HIV/AIDS incidence levels were below average accounting for the lower than expected contribution to output lost due to HIV/AIDS. Figure 7 below shows the distribution of output lost due to HIV/AIDS according to areas.

\section{Figure 2: distribution of output lost due to HIV/AIDS by Areas}
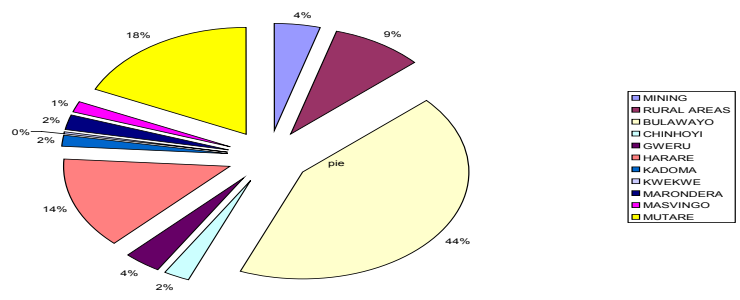

The results of the study show that the impact of HIV/AIDS on the Zimbabwean economy is enormous. The results obtained above may be an understatement of the true amount of output loss due to HIV/AIDS because the data used is likely to underestimate HIV/AIDS impact since the computation uses recorded data for the year 1994 up to 2004 yet the first HIV/AIDS case was recorded in 1987 in the country. Although HIV/AIDS incidence was small in the years before 1994, their inclusion would simply increase the computed output loss due to HIV/AIDS.

\section{Sensitivity analysis}

The results of this study are highly sensitive to progression rates from one stage to the other. A sensitivity analysis is thus carried out to establish the impact of changes in progression rates on output loss due to HIV and AIDS. The following progression rates shall be considered: one and two years lengthening of the asymptomatic stage, one and two years lengthening of the first phase of the symptomatic stage, and lastly a year lengthening of the second phase of the symptomatic stage. Percentage change in output loss due to HIV and AIDS for the different progression rates are presented in the table 3 below. 
Table 3: Sensitivity Analysis for Changes in Transition Periods

\begin{tabular}{|c|c|c|c|c|c|}
\hline \multicolumn{3}{|c|}{$\begin{array}{c}\text { asymptomatic } \\
\text { stage }\end{array}$} & $\begin{array}{c}\text { symptomatic } \\
\text { stage (phase 1) }\end{array}$ & $\begin{array}{c}\text { symptomatic } \\
\text { stage (phase 2) }\end{array}$ \\
\hline $\begin{array}{c}\text { Output lost due to HIV } \\
\text { and AIDS }\end{array}$ & $\mathbf{1}$ year & 2 years & 1 year & 2 years & 1 year \\
\hline $\begin{array}{c}\text { Nominal Output Loss } \\
\text { Output Lost -1994 prices }\end{array}$ & $24.82 \%$ & $46.59 \%$ & $7.20 \%$ & $12.60 \%$ & $2.13 \%$ \\
\hline Output Lost -2003 prices & $24.82 \%$ & $46.59 \%$ & $7.20 \%$ & $12.60 \%$ & $2.13 \%$ \\
\hline Output lost - Jan 1994 PV & $13.99 \%$ & $27.91 \%$ & $6.67 \%$ & $12.96 \%$ & $3.23 \%$ \\
\hline Morbidity & $22.72 \%$ & $42.60 \%$ & $6.87 \%$ & $12.35 \%$ & $2.32 \%$ \\
\hline
\end{tabular}

The analysis show increased robustness for changes in transition period for the asymptomatic (with $22.72 \%$ change in morbidity and $24.82 \%$ change in real output loss for a one year change) and phase one of the symptomatic (with $6.87 \%$ change in morbidity and $7.2 \%$ change in real output loss for a one year change) stages. The results of the study are credible given that they are more sensitive to the transition period of the asymptomatic change yet the data used in the model starts at the first phase of the symptomatic stage which has a $7.2 \%$ change in real output loss. This reduces real output loss due to HIV and AIDS by $1.67 \%$ only from $13.32 \%$ of 1993 Gross Domestic Product at factor cost to $11.6 \%$. The percentage reduction in real output loss due to HIV and AIDS by lengthening the second phase of the symptomatic stage is insignificant when translated into a proportionate reduction in 1993 GDP loss due to HIV and AIDS.

\section{Conclusion}

HIV/AIDS is the leading cause of morbidity and mortality in Zimbabwe. This has wide implications for the Zimbabwean economy as it affects the economy's capacity to accumulate human capital stock, diminishes labour supply as well as labour productivity. Using a human capital approach, the results of this study shows that HIV/AIDS led to a $13.32 \%$ of 1993's GDP. The computed figure may be an understatement of the true output loss because of a downward bias in recorded HIV/ AIDS incidence, however, they are a credible pointer to the impact HIV/AIDS has had on the Zimbabwean economy. This impact is significant and severe given that the effect of HIV/AIDS on the economy shall continue to be felt in many more years to come even if incidence falls to zero today. Thus, HIV/AIDS' impact on the macro-economy cannot be ignored and mitigatory measures need to be taken much more seriously as soon as possible. Such measures should aim at reducing HIV/ AIDS incidence and enhancing the lives of people living with HIV/AIDS whilst prolonging the transition period before one has AIDS and reducing illnesses in the symptomatic stage. This would eventually reduce the number of healthy life years lost due to HIV/AIDS morbidity on output. 


\section{Notes}

1. A version of this paper has also been presented as a ZEPARU Discussion paper

2. Corresponding author.contact Tel.+2634 331014, matshe@sociol.uz.ac.zW

3. University of Zimbabwe

4. Ministry of Health and Child Welfare, May 2004.

5. National Aids council, December 2003.

6. This has implications for production and the population age structure.

7. Kara Hanson (1992) “AIDS: What Does Economics Have to Offer?”, Health Policy and Planning Vol.7 No.4 pp.315

8. Kambou, Devarajon and Over (1992), "The Economic Impact of AIDS in an African Country: Simulations with a Computable General Equilibrium Model of Cameroon”, Journal of African Economies Vol.1 No.1 pp.109

9. http://clinicuelactuel.com/home/page/hiv

10. Murray C. J.L (1994), Technical basis for DALYs, WHO Bulletin OMS, Vol 72 pp.438

11. http://biotech.law.lsu.edu/cphl/Models/aids/chapter2.p

12. See appendix 1 for a detailed explanation on the construction of a transition matrix.

13. Central Statistics Office, (March 2002), "National Accounts 1985-2000”, pp.10.

14. These earnings differ across geographic areas depending on economic activities of those areas and the value of labour's contribution to output.

15. SAPES-UNDP-SADC, (2000), "SADC Regional Human Development Report 2000”, SAPES Books.

16. Ministry of Health and Child Welfare, 2004.

17. Ministry of Health and Child Welfare, May 2004.

18. Zimbabwe has embarked on a land redistribution scheme generally known as the Fast Track Land Resettlement Programme, where black farmers were resettled on previously white owned commercial land often violently displacing them without much due process.

\section{References}

Central Statistics Office, (March 2002), “National Accounts 1985-2000”, pp.10.

Haacker, M (2002), 'The economic consequences of HIV and AIDS in Southern Africa', IMF Working Paper.

Hanson, K. (1992) “AIDS: What Does Economics Have to Offer?”, Health Policy and Planning Vol.7 No.4 pp315 - 327

Hethcote, H.W., Van Ark, J.W., Longini IM Jr (Oct 1991) A simulation model of AIDS in San Francisco: I. Model formulation and parameter estimation., Fred Hutchinson Cancer Research Center. University of Washington..

http://biotech.law.lsu.edu/cphl/Models/aids/chapter2.p

http://clinicuelactuel.com/home/page/hiv

Loewenson., R and A. Whiteside (2001) 'HIV and AIDS: implications for poverty reduction', paper prepared for the UNDP for the UN General Assembly Special Session on HIV and AIDS, 25-27 June 2001.

Kambou, Devarajon and Over (1992), "The Economic Impact of AIDS in an African Country: Simulations with a Computable General Equilibrium Model of Cameroon”, Journal of African Economies Vol.1 No.1 pp109.

Kwaramba, P (1997) "The Socio-Economic Impact of HIV and AIDS on Communal Agricultural Systems in Zimbabwe, ” Zimbabwe Farmers Union, Friedrich Ebert Stiftung Economic Advisory Project, Working Paper 19.

Matinhure N, (2003) "The Demographic Impact of AIDS: Zimbabwe" Report for the Zimbabwe Human Development Report 2003, IDS, Zimbabwe.

Matshe, I. and T. Young, (2004) Off-farm Labour Allocation Decisions in Small-Scale Rural 
Households in Zimbabwe. Agricultural Economics 30 (6), 175-186.

Ministry of Health and Child Welfare Report, May 2004

Murray C. J.L (1994), Technical basis for DALYs, WHO Bulletin OMS, Vol 72 pp438

National Aids Council Report, December 2003.

Poverty Reduction Strategy (2004) Zimbabwe Human Development Report 2003 - Redirecting Our Responses to HIV and AIDS, IDS.

SAPES-UNDP-SADC, (2000), “SADC Regional Human Development Report 2000”, SAPES Books.

\section{Appendix 1- Transition Matrix}
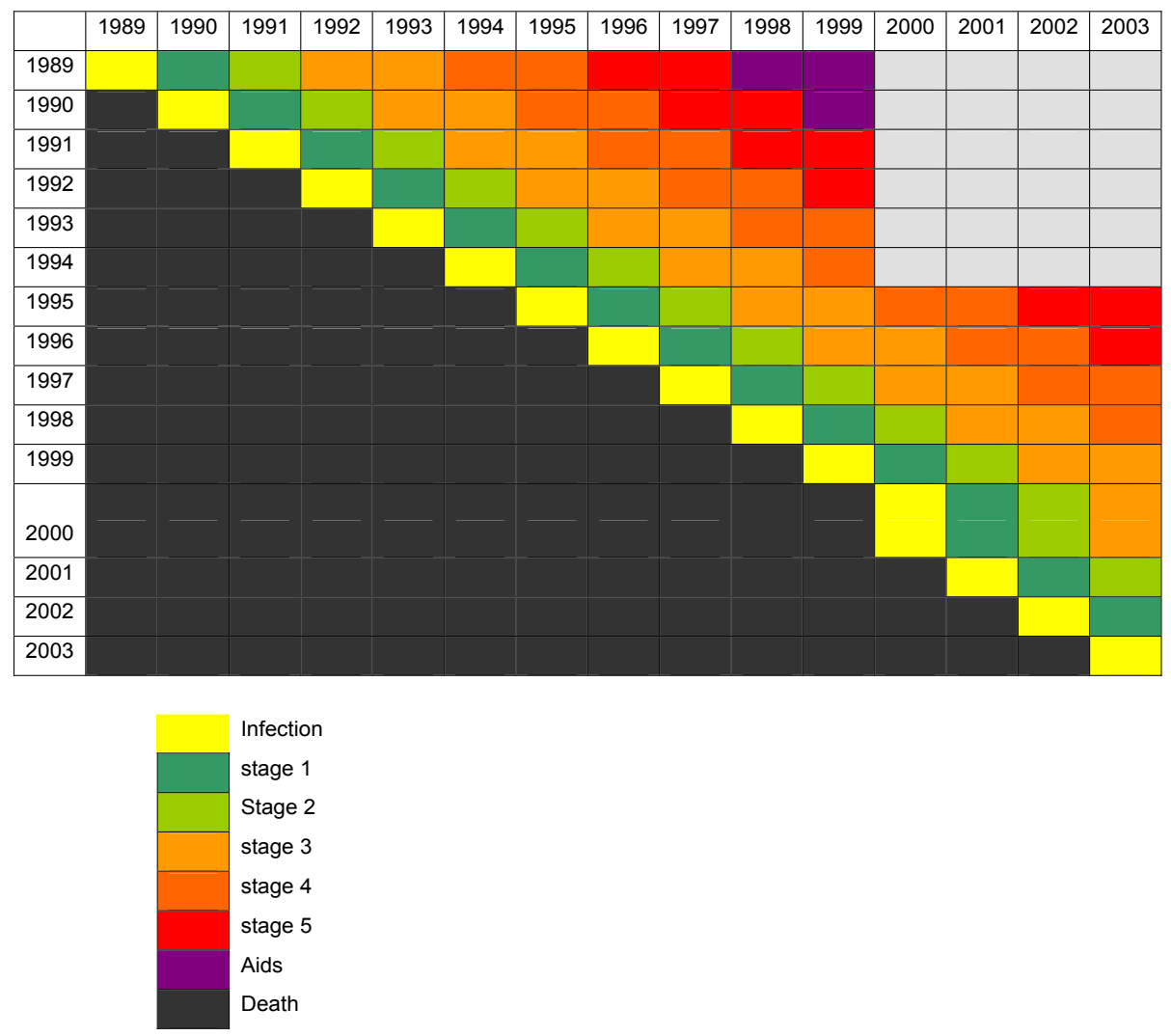

The figures along the main diagonal are the impact of HIV incidences in the respective periods e.g. the number of new HIV infected persons in a given point in year 2000. The prevalence in 2000 comprise incidences from each of the past periods and these persons will be in different stages of progression depending on the period in which they were infected and the transition period from one stage to the other. Using the transition rate in this study, prevalence in 2000 will comprise $n_{1}$ people infected in 1989 and now dead, $n_{2}$ people infected in year 1990 and now with AIDS, $n_{3}$ people infected in 1991 and now with AIDS, $\mathrm{n}_{4}$ people infected in 1992 and now in the second phase of the symptomatic stage (i.e. stage 5), $\mathrm{n}_{5}$ people infected in year 1993 and now in stage 5, $\mathrm{n}_{6}$ people infected in year 1994 and now in second phase of the asymptomatic stage (i.e. stage 4), and so on up to $n_{12}$ people infected in 2000 who are in the primo-infection stage. The same applies to the successive periods with prevalence increasing until people infected in earlier periods start to die. 